\title{
APPENDIX A: LIST OF PROFESSIONAL COUNSELING ORGANIZATIONS
}

(Note: Be aware licensing and credentialing requirements are subject to periodic change.)

\section{AMERICAN COUNSELING ASSOCIATION}

The American Counseling Association (ACA) is the flagship organization for counselors and the world's largest organization representing the counseling profession. All counselors should hold a membership in the ACA. Membership in the ACA also includes a subscription to the Journal of Counseling and Development, the monthly magazine Counseling Today, and numerous other tools for professional development.

The ACA (www.counseling.org) also includes 19 affiliate divisions representing various counseling specialties and many different counseling interest groups:

\section{- American College Counseling Association}

The American College Counseling Association (ACCA) is the primary professional organization for college, university, and community college counseling professionals. ACCA membership is also open to psychologists, social workers, and so forth.

www.collegecounseling.org

\section{- American Rehabilitation Counseling Association}

The American Rehabilitation Counseling Association (ARCA) represents the profession of rehabilitation, rehabilitation counseling faculty, and graduate students in rehabilitation counseling.

www.arcaweb.org

\section{- Association for Adult Development and Aging}

The Association for Adult Development and Aging (AADA) serves as the professional organization devoted to supporting counselors serving senior populations.

www.aadaweb.org 


\section{- Association for Assessment and Research in Counseling}

The Association for Assessment and Research in Counseling (AARC) promotes the ethical and effective use of assessment (testing) in the counseling profession. www.theaaceonline.com

\section{- Association for Child and Adolescent Counseling}

The Association for Child and Adolescent Counseling (ACAC) aims to focus on the training needs of counselors who work with children and adolescents while also providing professional support to those counselors, whether they are school counselors, play therapists, counselor educators, and so on.

www.acachild.com

\section{- Association for Counselor Education and Supervision}

The Association for Counselor Education and Supervision (ACES) is an umbrella organization for counselor educators in all counseling affiliates (clinical mental health counseling, school counseling, marriage and family counseling, etc.), as well as counseling supervisors out in the field. ACES membership is also open to counseling psychologists and members in related mental health professions.

www.acesonline.net

\section{- Association for Creativity in Counseling}

The Association for Creativity in Counseling (ACC) is a professional affiliate organization for creative arts counseling (e.g., art, music, dance, and drama therapy) as well as novel counseling approaches. ACC also encourages creative expression in the manner of poetry, prose, musical performance, and so forth, by individual counselors.

www.creativecounselor.org

\section{- Association for Humanistic Counseling}

The Association for Humanistic Counseling (AHC), formerly C-AHEAD, a founding association of the ACA in 1952, provides a forum for exchange of information about humanistic-oriented counseling practices and promotes changes that reflect the growing body of knowledge about humanistic principles applied to human development and potential.

www.afhc.camp9.org

\section{- Association for Lesbian, Gay, Bisexual, and Transgender Issues in Counseling}

The Association for Lesbian, Gay, Bisexual, and Transgender Issues in Counseling (ALGBTIC) educates counselors on concerns regarding the needs of lesbian, gay, bisexual, and transgender clients. The ALGBTIC also serves as an advocacy organization both within and beyond the counseling profession.

www.algbtic.org 


\section{- Association for Multicultural Counseling and Development}

The Association for Multicultural Counseling and Development (AMCD) strives to improve the understanding of multicultural issues in counseling. Multicultural issues could be related to race, sexual orientation, class, disability, culture, religion or spirituality, and many other issues.

https://multiculturalcounselingdevelopment.org/

\section{- Association for Specialists in Group Work}

The Association for Specialists in Group Work (ASGW) provides professional leadership and promotes research in the field of group counseling in schools, colleges/universities, correctional facilities, hospitals, and so forth.

www.asgw.org

\section{- Association for Spiritual, Ethical, and Religious Values in Counseling}

The Association for Spiritual, Ethical, and Religious Values in Counseling (ASERVIC) is devoted to exploring and addressing spiritual, religious, and ethical issues in counseling.

www.aservic.org

\section{- Counselors for Social Justice}

The Counselors for Social Justice (CSJ) is one of the newest ACA divisions and is committed to plurality on a broad array of social justice issues including an end to oppression and injustice impacting clients, students, families, communities, schools, workplaces, governments, and other social and institutional systems.

www.counseling-csj.org

\section{- International Association of Addictions and Offender Counselors}

The International Association of Addictions and Offender Counselors (IAAOC) advocates for the development of effective practice in substance abuse treatment, counseling juvenile offenders, and counselors working in correctional facilities.

www.iaaoc.org

\section{- International Association of Marriage and Family Counselors}

The International Association of Marriage and Family Counselors (IAMFC) is the ACA division devoted to studying and promoting the field of couples and family counseling.

www.iamfconline.org

- Military and Government Counseling Association (MGCA); formerly Association for Counselors and Educators in Government (ACEG)

The Military and Government Counseling Association (MGCA) is dedicated to exploring counseling issues and concerns in municipal, state, federal, and military settings.

www.acegonline.org 
- National Career Development Association

The National Career Development Association's (NCDA) mission is to promote career and vocational counseling and development. www.associationdatabase.com/aws/NCDA/pt/sp/Home_Page

- National Employment Counseling Association

The National Employment Counseling Association's (NECA) charge is professional leadership and development for counselors working in employment settings.

www.employmentcounseling.org

\section{ADDITIONAL PROFESSIONAL COUNSELING ORGANIZATIONS}

\section{- American Mental Health Counselors Association}

The American Mental Health Counselors Association (AMHCA) is the professional organization specifically representing clinical mental health counseling. www.amhca.org

\section{- American School Counselor Association}

The American School Counselor Association (ASCA) is an independent counseling organization promoting the profession of school counseling.

www.schoolcounselor.org

\section{ADDITIONAL PROFESSIONAL ASSOCIATIONS (INDEPENDENT OF THE AMERICAN COUNSELING ASSOCIATION)}

\section{- American Art Therapy Association}

The American Art Therapy Association (AATA) is an organization of professionals dedicated to using art in a therapeutic, healing manner. The AATA provides standards of professional competence and promotes knowledge in the field of art therapy.

www.arttherapy.org

\section{- American Association of State Counseling Boards}

The American Association of State Counseling Boards (AASCB) promotes unification and reciprocity among U.S. state counseling licensure requirements.

www.aascb.org

\section{- American Dance Therapy Association}

The American Dance Therapy Association (ADTA), founded in 1986, is a professional organization dedicated to the profession of dance/movement therapy. www.adta.org 


\section{- American Music Therapy Association}

The American Music Therapy Association (AMTA) was unified in 1998 to support the development of the therapeutic use of music in counseling and therapy.

www.musictherapy.org

\section{- American Society of Group Psychotherapy and Psychodrama}

The American Society of Group Psychotherapy and Psychodrama (ASGPP) was founded in 1942 to support therapeutic uses of drama.

www.asgpp.org

\section{- Association for Play Therapy}

The Association for Play Therapy (APT) is a national professional society established in 1982 to foster contact among mental health professionals interested in exploring the therapeutic power of play to treat clients, particularly children.

www.a4pt.org

\section{- International Association of Counseling Services}

The International Association of Counseling Services (IACS) serves as the professional accrediting organization for college and university counseling centers and community clinics.

www.iacsinc.org

\section{- International Association of Counselors and Therapists}

The International Association of Counselors and Therapists (IACT) is the professional counseling organization promoting the international counseling profession.

www.iact.org

\section{PROFESSIONAL ACCREDITING ORGANIZATIONS FOR THE COUNSELING PROFESSION}

\section{- Center for Credentialing and Education}

The Center for Credentialing and Education (CCE), an affiliate of the National Board for Certified Counselors, Inc., provides credentialing to counselors and related professionals. The CCE offers several certifications including Approved Clinical Supervisor (ACS), Distance Certified Counselor (DCC), Board Certified Coach (BCC), and several more.

www.cce-global.org 


\section{- Commission on Rehabilitation Counselor Certification}

The Commission on Rehabilitation Counselor Certification (CRCC), like the NBCC, provides certification for individual rehabilitation counselors. Certification, unlike licensure, is usually a voluntary credential for counselors. Licensure, often a mandatory credential, is overseen by state licensure boards (see State Licensure Boards).

www.crccertification.com

\section{- Council for Accreditation of Counseling and Related Educational Programs (CACREP)}

The CACREP, an ACA organizational affiliate, is the international accrediting organization for counseling programs. The CACREP accredits graduate counseling programs in colleges and universities. The types of graduate counseling programs accredited by the CACREP are doctoral programs in counselor education, as well as master's degree programs in clinical mental health counseling, marriage and family counseling, school counseling, student affairs and counseling, college counseling, and most recently clinical rehabilitation counseling.

www.cacrep.org

email: cacrep@cacrep.org

\section{- National Board for Certified Counselors}

The National Board for Certified Counselors (NBCC) serves as an independent credentialing organization for the counseling profession. Although U.S. states and territories are responsible for licensing counselors, the NBCC provides certification for specialty areas. Examples of NBCC specialty area certifications are the National Certified Counselor (NCC), National Certified Clinical Mental Health Counselor (NCCMHC), National Certified Career Counselor (NCCC), and Approved Clinical Supervisor (ACS). The NBCC also offers certification examinations that most U.S. states and territories use for licensure examinations, such as the National Counselor Examination (NCE), Certified Clinical Mental Health Counselor Examination (CCMHCE), and more.

www.nbcc.org

email: nbcc@nbcc.org

\section{ADDITIONAL WEBSITE OF INTEREST}

- The U.S. Bureau of Labor Statistics

The U.S. Bureau of Labor Statistics (BLS) compiles and publishes the online Occupational Outlook Handbook $(\mathrm{OOH})$, a publication that offers growth projections for thousands of occupations. The $\mathrm{OOH}$ covers counseling and related occupations. The BLS OOH publication is very important for tracking growth in the counseling profession.

www.bls.gov/ooh 